\title{
Active Learning Methodologies in a Solar Power, Middle-Grade Curriculum for Palestinian Schools
}

\author{
Peter Rillero $^{1}$, Alissa Koerner ${ }^{1}$, Abdel Karim Daragmeh² ${ }^{\text {Kozan Soykal }}{ }^{1}$
}

\author{
${ }^{1}$ Arizona State University, UNITED STATES \\ ${ }^{2}$ Najah National University, PALESTINE \\ *Corresponding Author: rillero@asu.edu
}

Citation: Rillero, P., Koerner, A., Daragmeh, A. K., \& Soykal, K. (2020). Active learning methodologies in a solar power, middle-grade curriculum for Palestinian schools. Interdisciplinary Journal of Environmental and Science Education, 16(2), e2211. https://doi.org/10.29333/ijese/7814

\begin{abstract}
ARTICLE INFO ABSTRACT
Received:

31 December 2019

Palestine has great potential for solar energy use because of its status as an occupied territory with accompanying energy challenges and the area's ample amounts of sunshine. Solar energy education and the incorporation of active-learning methods can promote learning about key scientific concepts, environ-

Accepted:

23 February 2020 mental benefits, and uses of solar energy, while developing problem-solving and inquiry abilities. A grades six to nine curriculum on solar energy for Palestinian schools is described, which uses structured inquiry, problem-based learning, and multimedia animated videos. The format for the activities is exploration occurs first followed by concept formation using the videos and discussions. A three-day teacher workshop led participants through the experiences. A subsequent implementation in schools was observed. Participants had overall positive attitudes toward the curriculum, the active-student learning methods, their abilities to implement, and the positive effects the program would have on student learning.
\end{abstract}

Keywords: solar energy, inquiry, problem-based learning, middle school, Palestine, photovoltaics, animation

\section{INTRODUCTION}

The replacement of fossil fuels with solar power can lead to less carbon dioxide emissions and greater energy independence. The status of Palestine as an occupied territory with infrastructure challenges and its abundance of sunshine make it one of the best places in the world for solar power, including solar water heating and photovoltaics.

Formal education across the Middle East and North Africa (MENA) may not adequately prepare students for careers and life because of a greater focus on credentials than actual skills (Assaad, Krafft, \& Salehi-Isfahani 2018; Salehi-Isfahani, 2012). The curricula in MENA countries tends to focus more on rote memorization than the development of essential skills (Faour, 2012). According to Martin, Mullis, Foy, and Hooper (2006), grade 8 MENA students spend twice as much class time memorizing in science and math than the international averages. There are calls for helping MENA teachers who have strong content knowledge, use innovative teaching strategies to promote critical thinking (OECD, 2012).

Solar power education can help Palestinian youth use this resource later in their lives and it can have career-path potential. Transitioning instruction from didactic teaching to more active student learning methodologies will better enable Palestinians to find solutions for current and future challenges. This article describes a solar power program for middle school students in Palestine, an activity sequence for a unit, and teacher views of the program.

\section{Educational Challenges and Opportunities in Palestine}

From the Ottomans, to the British, and then to the Israelis, education in occupied Palestinian Territories has been controlled by foreign rule (Ramahi, 2019). The first Palestinian Ministry of Education was created in 1994, and the nascent system has many challenges. Palestinian students were ranked in the bottom fifth for the assessment by the International Mathematics and Science Study in 2003, 2007, and 2011 (Palestinian Ministry of Education and Higher Education, 2011), with no participation in 
later years. A large and growing gap between the critical thinking and soft skills that young learners need to develop and those that are emphasized by the teaching and assessment practices in the Palestinian school education is widely acknowledged (Zamel, 2016). Despite efforts invested in re-designing curriculum, often with the involvement of the international donor community, the textbook-based education and the traditional assessment practices remain quite common in Palestinian schools (Abualrob \& Al-Saadi, 2019). Perhaps the greatest challenge is the prevailing conception that "top-down, non-participatory modes of teaching were identified as reinforcing a passive, submissive approach to learning and life" (Ramahi, 2015, p.8).

\section{Solar Power}

It is widely acknowledged that the use of renewable energies instead of fossil fuels in developing countries offers important sustainable solutions with economic, environmental and social impacts (Thiam, 2011). Around the globe, these solutions have high potential to be cost-efficient and reliable as well as non-damaging to the environment. They provide local employment opportunities and access to energy in rural or remote areas (Thiam, 2011; Hamed, Flamm, \& Azraq, 2011).

Because of the specific political, economic, environmental, geographic, and infrastructural conditions in the State of Palestine, this potential impact is even greater than in other contexts (Hamed, Flamm, \& Azraq, 2011). Currently lacking a secure, stable, and sufficient energy system, due in part to Israeli occupation of its territories, Palestine relies upon Israel, Jordan, and Egypt for fossil fuel and electricity imports (Marei, 2016). Energy insecurity in Palestine often impedes community and economic development and imported energy comes at a high financial cost to its residents.

Although Palestine is nearly devoid of gas and oil resources within its borders, it is rich in solar resources and has an annual average of 5.4 peak sun hours per day (Natsheh, 2016). By making use of this highly available, renewable resource through large-scale and stand-alone applications, Palestine has the potential to reduce its energy dependence upon other countries and to make energy accessible to vulnerable populations in remote areas.

Solar energy can be used for heating homes and water and also for the generation of electricity. A photovoltaic (PV) cell generates electric energy from sunlight. The continual development of and improvement upon both solar thermal and PV technologies will only be possible by educating future generations in solar power and related concepts. Almost $70 \%$ of households in Palestine are currently equipped with solar water heaters, providing a high level of context and relevance for most Palestinian students upon which these concepts can be built (RCREE, 2013).

\section{Active Learning Methodologies}

There is a continuum between teacher-centered instruction and student-centered learning. Teachingcentered instruction is dominated by the lecture method and textbook use. Student-centered learning features students in more active methods of learning (Dole, Bloom, \& Kowalske, 2016). There is a long-history of incorporating practical work and laboratories into science instruction. These experiences, however, can be infrequent due to lack of equipment and materials and striving to cover large amounts of content (Haury \& Rillero, 1994).

Activities requiring student manipulation and thought are essential in the transition from teacher-centered instruction to student-centered learning. When students have alternative conceptions about energy, an inquiry approach was favored over direct instruction for conceptual development (Afra, et al., 2009). Science activities vary in how much decision making is afforded to students. This is illustrated with a description of two types of science activity: Structured Inquiry and Problem-Based Learning (PBL).

Not all active-learning needs to be hands-on learning. The Predict-Explain-Test-Explain (PETE) method was adapted from the White and Gunstone's (1992) PredictObserve-Explain (POE) method, which was adapted from the Demonstrate-Observe-Explain (DOE) method (Champagne, Klopfer \& Anderson, 1979). In the approach students are given a context, typically as a demonstration, then make a prediction with an explanation for the prediction. In the Test phase students observe the phenomena, and then in the final Explan they seek to explain with the teachers' support. The PETE method promotes learning but also helps teachers evaluate student understanding and possible alternative conceptions.

\section{Structured Inquiry}

In structured inquiry, the teacher provides the question and the procedure (Banchi \& Bell, 2008). Students typically use hands-on materials to make observations and collect data. They generate an explanation based upon the data. There has been movement away from confirmatory activities, with goals to "prove" a concept that has already been taught, towards a more discovery approach. In this context, student exploration, the doing of the activity, precedes explanation, which uses the experience for teachers and students to develop the science concept. Thus, the 5-E learning cycle with stages of 
Engage, Explore, Explain, Elaborate, and Evaluate is often used as a framework for inquiry (Bybee \& Landes, 1990; Rillero, 1999).

\section{Problem-Based Learning}

While ideas related to PBL can be traced back to Dewey (1938), PBL was firmly established in medical education in the 1970s, with origins at McMaster University (Barrows, 1996; Barrows \& Tamblyn, 1980; Zubaidah, 2005). Challenging the existing lecture and memorize method, medical students learned content and clinical reasoning abilities by identifying symptoms in real patients and simulated patients or written case studies (Barrows \& Tamblyn, 1980), diagnosing medical conditions, and prescribing treatments (Barrows, 1996). From medical education, PBL entered into other professional education programs including architecture, engineering, advertising, nursing, physical therapy, and business administration (Barrows, 1996; Gould \& Sadera, 2015; Quinn \& Albano, 2008; Rideout \& Carpio, 2001; Zubaidah, 2005).

In PBL, the problem comes before instruction on how to solve it, or in other words student exploration precedes explanations (Loyens, Magda, \& Rikers, 2008). Our operational definition of the approach is: "Problem-Based learning is an instructional approach where learners grapple with meaningful problems and collaboratively work toward their resolution."

The move of PBL into grades K-12 education necessitated a broader view from foci on clinical skills or problem-solving for a single profession to $\mathrm{K}-12$ experiences designed to prepare learners for many possibilities in life (Delisle, 1997; Marle et al., 2012; Torp \& Sage, 2002). Studies of pre-university implementations are limited and frequently have conflicting results (Wirkala, \& Kuhn, 2011). A recent systematic literature review for science education, involving control-groups with $\mathrm{PBL}$ as the independent variable, however, provides evidence that grades $\mathrm{K}-8$, science, PBL experiences foster academic achievement, knowledge retention, conceptual development, and improved attitudes (Merritt, Lee, Rillero, \& Kinach, 2016).

\section{Video Animation as a Content Scaffold}

Animations use drawings, photographs, and images to create the illusion of movement. Multimedia incorporates both visual and auditory materials. The Cognitive Theory of Multimedia learning (Mayer, 2005) is influential in animation use and contains three theoretical principles (Yarden \& Yarden, 2010). The dual-channel principle posits separate learning channels for visual and auditory information suggesting better learning with activation of both channels. The limited-capacity principle suggests that only a few pieces of information can be processed in a short time. The application of both of these constructions may lead to the creation of animations with greater potential to achieve meaningful learning.

The active-processing assumption postulates meaningful learning occurs with active cognitive processes, which can be combining the multimedia product with prior experiences or knowledge. Thus, "the role of the teacher while enacting the animations in class appears to be extremely important" (Yarden \& Yarden, 2011, p. 200).

\section{Inservice Teacher Education for Student-Centered Learning}

A body of research suggests that inquiry teaching has positive effects on student learning (Haury \& Rillero, 1994; Minner, Levy, \& Century, 2010). The challenges of implementing this type of instruction, however, necessitate professional development opportunities for inservice teachers (Krajcik, Mamlok, \& Hug, 2001).

Kanesa, Philippoff, Parisky, Degnan, \& Diana (2013) found that inservice teacher workshops motivated teachers to integrate energy science into their teaching and they did so across a range of disciplines. Compared to other workshops they conducted, they found that the teachers' knowledge of energy concepts was low compared to other subjects. Further, these teachers had lower confidence for implementing inquiry methods for energy. Nevertheless, they found the workshops had a positive effect on the teachers' abilities to teacher energy science using inquiry.

\section{Solar Energy Curriculum}

The goals of the curriculum and professional development were to: (a) assist teachers in implementing student-centered learning, (b) deepen middle-school students' knowledge of solar power, and (c) develop student inquiry and problem-solving abilities.

The curriculum is divided into three units. The first unit is about solar thermal energy and explores related concepts like heat gain, absorption, and insulation. The second unit focuses on solar photovoltaic energy. This unit covers basics of circuits and has activities related to photovoltaic cells in circuits. The last unit is about solar energy as a solution to Palestine's electricity problem. This unit compares solar with other energy sources.

At the conclusion of each unit, students are posed with learning situations which demand they apply their newly gained knowledge in order to design solar based energy solutions which meet the needs of their local communities in Palestine. 


\section{Structured Inquiry}

Each unit of the program starts with basic activities that has students recall prior knowledge. The activities are scaffolded as students deepen their learning. To illustrate the approach, we discuss the structure of the unit on photovoltaic solar power in detail and provide links to activity sheets and a video.

The first activity of the unit has students building simple circuits with batteries, wires, switches and bulbs. As an introductory activity, it engages the students in the topic and then deepens their learning. This activity is followed by a video that further develops their understanding of electricity. The video can be accessed through the following links: http://bit.ly/EKPPVSolarVidEN (English) and http://bit.ly/EKPPVSolarVidAR (Arabic).

In the second activity, students measure voltage across batteries using a multimeter. This activity introduces voltage and how to use multimeters. Students also connect batteries in different ways and measure the voltage change in these connections, as a preparation for the next two activities introducing series and parallel circuits. In "Measuring Voltage in Parallel and Series Circuits" (http:// bit.ly/EKPActivity2-4), students explore how voltage changes in the circuit. After the activity, students watch a video describing series and parallel circuits.

For the fifth activity, "Solar Panels and Buzzer" (http:// bit.ly/EKPActivity2-5), a photovoltaic cell replaces batteries in a circuit and the load is an inexpensive sound board. Here, students observe how the (a) angle and (b) number of PV cells affects the load. This activity is followed by a video explaining how photovoltaic cells can produce electricity from solar energy.

\section{Problem-Based Learning}

In "Solar-Powered Water Pump Design Challenge" (http://bit.ly/EKPActivity2-6), the last activity of the unit, students design and build a circuit that has a water pump as the load and is powered by photovoltaic cells. The goal is to pump water to a height of 1 meter and achieve maximum possible flow. The previous structured inquiry activities provide scaffolds for the design. The work of students is shared through a gallery walk format. The PETE method was also used to promote problem-based, active learning.

\section{Teacher Workshop}

A three-day workshop on the solar energy curriculum (grades 6 to 9) and methods of teaching, particularly the $5 \mathrm{E}$ inquiry model and $\mathrm{PBL}$, was conducted. The participants consisted of ten science and technology teachers, five science and technology supervisors, four representatives from the curriculum development unit in the Ministry of Education and Higher Education, and four from a non-governmental organization.

While some theoretical background was provided, the majority of the time was used to have participants experience the curriculum as though they were middle grade students. Teacher behaviors in how to conduct inquiry and PBL activities was modeled. Teacher participants were prompted to reflect on the learning they experienced in their roles as middle grade students.

\section{Student Implementation}

The trained teachers implemented the hands-on units of study in three target schools during a three-month period. The teachers met with the pupils on Saturday for 2-4 hours. All pupils finished the program and completed the solar energy projects assigned to them. A project fair was organized held in the city of Ramallah. The project fair provided the suitable platform for the students to present their innovative projects which addressed several local energy challenges facing their immediate communities. They presented solar powered solutions as part of their project work.

More than 100 visitors representing a wide range of stakeholders visited the fair. Parents, government officials, school and university students, and educators from other institutions toured the exhibition stands and listened to student teams' presentations of project ideas and solar powered mechanisms.

\section{METHODS}

A mixed methods approach, using surveys, naturalistic observations, and semi-structured interviews, explored impact and effectiveness of the curriculum and professional development. Specific research questions that were addressed as part of this tailored intervention:

- What are participant perspectives of and confidence in implementing active-student learning methods?

- What are participant perspectives of the implementation in the Palestinian school context?

\section{Professional Development Data}

Data for this intervention were collected using a printed survey. The survey items were designed to tap the opinions of workshop participants on the benefits from the training and to collect formative feedback on the energy curriculum and the program implementation.

\section{Implementation Data}

The Palestinian teachers implemented the materials 
in three schools. Classroom observations were conducted to determine whether: a) the learning environment facilitated active, inquiry-based learning; $b$ ) the teachers were using the solar energy materials and videos and for which purposes; and c) the materials were perceived to be relevant to the Palestinian context.

\section{RESULTS}

\section{Professional Development Workshop}

All 23 participants completed the questionnaire. Nine of the workshop participants were female teachers and 14 were male. Eleven teachers who participated in the workshop had 15 years or more teaching experience; nine had 10-15 years experience; and three had 1-5 years. The observers written observations noted participants' high level of engagement with the prediction, exploration, observation or explanation tasks assigned by the facilitators over the three days.

The teachers who participated in the training workshops were asked to express their agreement with the evaluation components on a scale which ranged from (disagree strongly, disagree, agree, agree strongly and neutral). Seven questions gauged participants' satisfaction with the workshop content and design. The strongly agree percentages, agree percentages, means, and standard deviations came as follows: clarity of workshop objectives (74\% strongly agree, $26 \%$ agree, mean $=4.70$, $\mathrm{SD}=0.43)$; meeting workshop objectives $(69 \%, 31 \%, 4.70$, $0.56)$; the variety of activities and methods ( $17 \%, 78 \%$, $4.10,0.44)$; relevance of the activities and methods to solar energy $(48 \%, 52 \%, 4.50,0.50)$; clarity of purpose for the used methods (70\%, 30\%, 4.50, 1.05); relevance and usefulness to the middle school context $(74 \%, 26 \%, 4.80$, $0.17)$; and finally the appropriateness of materials to the middle school context $(70 \%, 30 \%, 4.70,0.46)$.

Seven questions were used to solicit participants' responses on the relevance of the materials to the Palestinian school and community context, their suitability to the level of 6-9 graders in Palestine, the feasibility of the assigned projects, and the quality of the outcomes. The strongly agree percentages, agree percentages, means, and standard deviations responses to the evaluation items were distributed as follows: appropriateness of the materials to the middle school context (39\%, $61 \%$, 4.20, 1.01); appropriateness of the activities to the learners level (61\%, 39\%, 4.60, 0.50); confidence in the pupils' abilities to execute the projects $(48 \%, 52 \%, 4.50,0.50)$; confidence in the quality of the projects $(65 \%, 35 \%, 4.30$, $1.40)$; learners' engagement with the activities $(61 \%, 39 \%$, $4.60,0.50)$; enhancing pupils' knowledge in the solar science $(61 \%, 39 \%, 4.70,0.46)$; and finally enhancing pupils' life skills $(61 \%, 35 \%, 4.40,1.05)$.
The next section in the questionnaire was designed to measure the participants' confidence in their own skills both as teachers of inquiry and problem-based energy curriculum and-for an added measure on confidence-trainers of new teachers on using this learning approach. Figure 1 shows the responses to the eight questions targeting important skills like project design, coaching learners, assessing learning, and coaching other teachers.

The items means and standard deviations were distributed as follows: ability to design projects for science curriculum $(4.20,0.65)$; ability to design learning outcomes for energy projects $(4.20,0.56)$; enhanced skills in assessing student learning $(4.20,0.7)$; enhanced coaching skills (4.4, 0.64); ability to implement problem based learning curriculum $(4.30,0.60)$; enhanced facilitation skills $(4.20$, 0.62 ); ability to identify problems related to energy in Palestine $(4.20,0.63)$; ability to train other teachers on PBL $(4.30,0.7)$.

\section{The Implementation of Interactive, Hands-On Units of Study}

Observers attended classroom sessions at in all three schools. These sessions lasted for three hours and included observation of solar energy activities, solar energy videos, and project work and display. The observation was intended to review the facilitation and process of

Perspectives on participant skill development

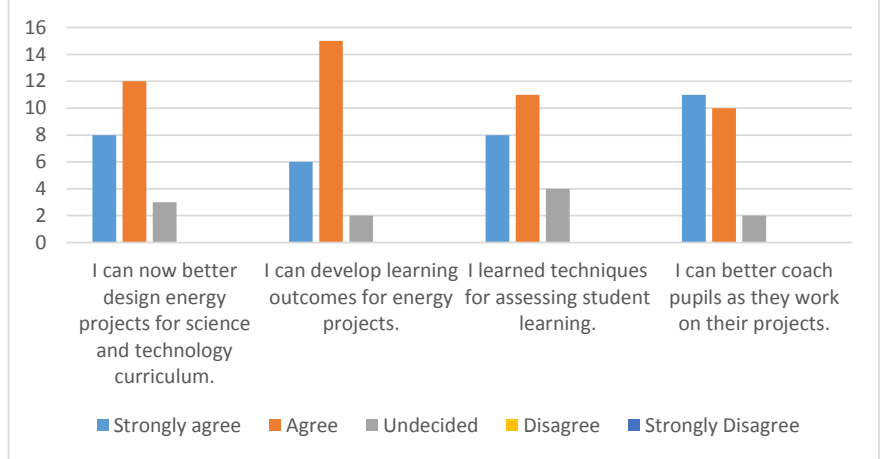

Perspectives on participant skill development

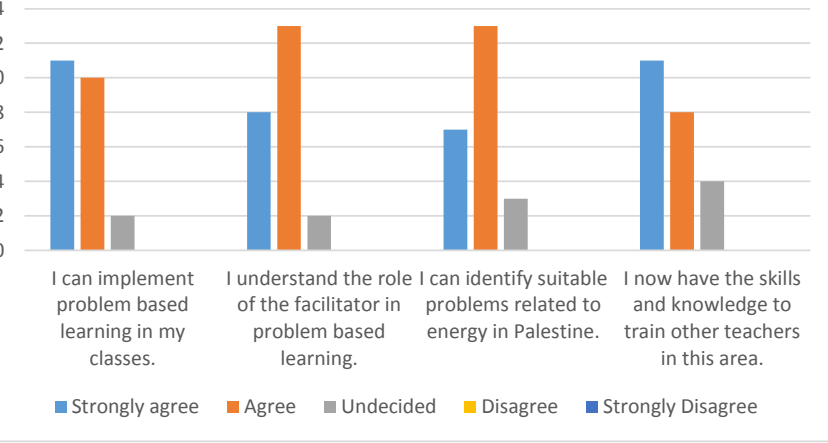

Figure 1. Graphical representations on survey items. 
implementing PBL solar energy curriculum in the target schools.

The following are observations that suggested differences between the boys' and girls' schools: (a) instructions were given as mandates at the boys' school, whereas at the girls' school students were invited into the challenges; (b) teachers at the boys' school answered student questions directly, whereas in the girls' school they often used questions to prompt further inquiries; (c) teachers at the girls' school better integrated the videos into the explain portions of the learning, and (d) overall, the girls' schools showed a stronger movement from teacher-centered instruction to student-centered learning.

\section{CONCLUSIONS AND RECOMMENDATIONS}

The solar energy program, which included knowledge content, PBL activities, and educational videos, was implemented with grades 6-9 in Palestine. The researchers have used appropriate measures to collect data on the effectiveness of the pedagogical model, the educational materials, and the teacher training workshops.

The observations and data suggest that the solar energy curriculum and activities were successfully implemented in the Palestinian school context. The designs were simple; the language was clear; and the activities were easy to implement with the Palestinian pupils. The positive responses towards the curriculum from teachers and supervisors were perceived as encouraging indicators that middle school children can do the required project work at the right level of quality.

The collaborative group work and learner-centered activities yielded quality projects and significant enhancement in the pupil's skills. There were differences in implementation between girls' and boys' schools, which had female and male teachers, respectively. The female teachers had greater movement towards student-centered learning. Future research should explore the reason for these differences.

Overall, the effort invested in empowering the Palestinian middle school kids has yielded encouraging results at the levels of curriculum design, updating learning methodologies, and generating interest in solar energy. The training model, the experimentation with the new curriculum and the problem-based learning pedagogy were both relevant and feasible in the Palestinian school context. Curriculum development and professional development for teachers used to didactic means, may be effective in promoting activity-based learning about energy concepts.

\section{REFERENCES}

Abualrob, M. M. A., \& Al-Saadi, S. H. (2019). Performance-based assessment: Approach and obstacles by higher-elementary science teachers in Palestine. Journal of Education and Learning, 8(2), 198-206. https://doi.org/10.5539/jel. v8n2p198

Assaad, R., Krafft, C., \& Salehi-Isfahani, D. (2018). Does the type of higher education affect labor market outcomes? Evidence from Egypt and Jordan. Higher Education, 75(6), 945-95. https://doi.org/10.1007/s10734-017-0179-0

Afra, N. C., Osta I., \& Zoubeir, W. (2009). Students alternate conceptions about electricity and effect of inquiry-based teaching strategies. International Journal of Science \& Mathematics Education, 7(1), 103-132. https://doi. org/10.1007/s10763-007-9106-7

Banchi, H., \& Bell, R. (2008). The many levels of inquiry. Science and Children, 46(2), 26-29.

Barrows, H. S. (1996). Problem-based learning in medicine and beyond: A brief overview. In L. Wilkerson \& W. H. Gijselaers (Eds.), Bringing problem-based learning to higher education: Theory and practice (pp. 3-12). San Francisco: JosseyBass.

Barrows H. S. \& Tamblyn R. M. (1980). Problem-based learning: an approach to medical education. New York: Springer Publishing Company.

Bybee, R., \& Landes, N. M. (1990). Science for life and living: An elementary school science program from Biological Sciences Improvement Study (BSCS). The American Biology Teacher, 52(2), 92-98.

Champagne, A. B., Klopfer, L. E. \& Anderson, J. (1979). Factors influencing the learning of classical mechanics. University of Pittsburgh.

Delisle, R. (1997). How to use problem-based learning in the classroom. Alexandria, VA: Association for Supervision and Curriculum Development.

Dewey, J. (1938). Experience and education. New York, NY: Simon \& Schuster.

Dole, S., Bloom, L., \& Kowalske, K. (2016). Transforming Pedagogy: Changing Perspectives from Teacher-Centered to Learner Centered. Interdisciplinary Journal of ProblemBased Learning, 10(1). https://doi.org/10.7771/15415015.1538.

Faour, M. (2012). The Arab world's education report card: School Climate and Citizenship Skills. Washington DC: Carnegie Middle East Center.

Gould, K. \& Sadera, W. (2015). Evaluation of health profession student attitudes toward an online nutrition education problem-based learning module. International Journal on E-Learning, 14(2), pp. 181-198.

Hamed, T. A., Flamm, H., \& Azraq, M. (2011). Renewable energy in the Palestinian Territories: Opportunities and challenges. Renewable and Sustainable Energy Reviews, 16, 1082-1088. https://doi.org/10.1016/j.rser.2011.10.011

Haury, D. L., \& Rillero, P. (1994). Perspectives of hands-on science teaching and learning (pp. 142). Columbus, OH: ERIC Clearinghouse for Science, Mathematics, and Environmental Education.

Kanesa, D. S., Philippoff, J., Parisky, A., Degnan, K., \& Diana, P. W. (2013). Teaching energy science as inquiry: Reflections on professional development as a tool to build inquiry teaching skills for middle and high school teachers. Journal of Science Education and Technology, 22(3), 235-251. http://dx.doi.org. ezproxy1.lib.asu.edu/10.1007/s10956-012-9389-5

Krajcik, J., Mamlok, R., \& Hug, B. (2001). Learning science through inquiry. In L. Corno (Ed.), Education across a century: The centennial volume (pp. 205-238). Chicago, IL: Chicago 
University Press.

Loyens, S. M. M., Magda, J. \& Rikers, R. M. J. P. (2008). Selfdirected learning in problem-based learning and its relationships with self-regulated learning. Educational Psychology Review, 20, 411-427. https://doi.org/10.1007/ s10648-008-9082-7.

Marei, I. (2016). Developments in law and policy: The promotion of green energy in the electricity sector of Palestine. Journal of Energy and Natural Resources Law, 35(1), 47-67. https:// doi.org/10.1080/02646811.2016.1216698

Martin, M.O., Mullis, I.V.S., Foy, P., \& Hooper, M. (2016). TIMSS 2015 International Results in Science. Retrieved from http:// timssandpirls.bc.edu/timss2015/international-results/.

Mayer, R. E. (2005). Cognitive theory of multimedia learning. In R. E. Mayer (Ed.), The Cambridge handbook of multimedia learning (p. 31-48). Cambridge University Press.

Merritt, J. D., Lee, M. Y., Rillero, P., \& Kinach, B. (2017). Problembased learning in K-8 mathematics and science education: $\mathrm{A}$ literature review. Interdisciplinary Journal of Problem-Based Learning, 11(2). https://doi.org/10.7771/1541-5015.1674

Minner, D. D., Levy, A. J., \& Century, J. (2010). Inquiry-based instruction. What is it and does it matter? Results from a research synthesis years 1984 to 2002 . Journal of Research in Science Teaching (47), 474-496. https://doi.org/10.1002/ tea.20347

National Environmental Education \& training Foundation. (2002) Americans' low "energy IQ:" a risk to our energy future/why America needs a refresher course on energy. National Environmental Education \& Training Foundation, Washington, DC.

Natsheh, E. M. (2016). Power generation of solar PV systems in Palestine. Applied Solar Energy, 52(3), 193-196.

OECD. (2012). Preparing teachers and developing school leaders for the 21st century: Lessons from around the World. Paris: OECD.

Palestinian Ministry of Education and Higher Education. (2011). Results of Palestine students in TIMSS. Department of Measurement, Evaluation and Examinations, Ramallah, Palestine.

Quinn, K., \& Albano, L. (2008). Problem-based learning in structural engineering education. Journal of Professional issues in Engineering Education and Practice, 134(4), 329-334. https://doi.org/10.1061/(ASCE)1052-3928(2008)134:4(329)

Ramahi, H. (2015). Education in Palestine: Current challenges and emancipatory alternatives. Rosa Luxemburg Stiftung. Retrieved from http://www.rosaluxemburg.ps

Ramahi, H. (2019). Supporting teacher leadership in palestine: an emancipatory approach. International Journal of Teacher Leadership, 10(1), 27-40.

RCREE. (2013). Palestine: Renewable energy country profile. Cairo: RCREE.

Rideout, E. \& Carpio, D. (2001). The problem based learning model of nursing education. In E. Rideout (Ed.), Transforming nursing education through problem based learning (pp. 2147). Mississauga: Jones and Bartlett Publishers Inc.

Rillero, P. (1999, June). Raphanus sativus, germination, and Inquiry: A learning cycle approach for novice experimenters. Electronic Journal of Science Education, 3(4). Retrieved from https://wolfweb.unr.edu/homepage/crowther/ejse/rillero. html

Salehi-Isfahani, D. (2012). Education, jobs, and equity in the Middle East and North Africa. Comparative Economic Studies, 54(4), 843-861.
Thiam, D. R. (2011). An energy pricing scheme for the diffusion of decentralized renewable technology investment in developing countries. Energy Policy, 39(7), 4284-4297.

Torp, L., \& Sage, S. (2002). Problems as possibilities: Problembased learning for K-16 education. Alexandria VA: Association for Supervision and Curriculum Development.

Yarden, H., \& Yarden, A. (2011). Studying biotechnological methods using animations: The teacher's role. Journal of Science Education and Technology, 20, 689-702. https://doi. org/ 10.1007/s10956-010-9262-3

White, R. T., \& Gunstone, R. F. (1992). Probing understanding. Great Britain: Falmer Press.

Wirkala, C., \& Kuhn, D. (2011). Problem-based learning in K-12 education: Is it effective and how does it achieve its effects? American Educational Research Journal, 48(5), 1157-1186. https://doi.org/10.3102/0002831211419491

Zamel, M. (2016). Palestinian teachers' classroom practices in light of the 21st century skills. Retrieved from http://www. hebron.edu/docs/journal/B-Humanities/v11-2/v11-2.124156.pdf.

Zubaidah, S. (2005). Problem-based learning: Literature review. Singapore Nursing Journal, 32(4) 50-55. 